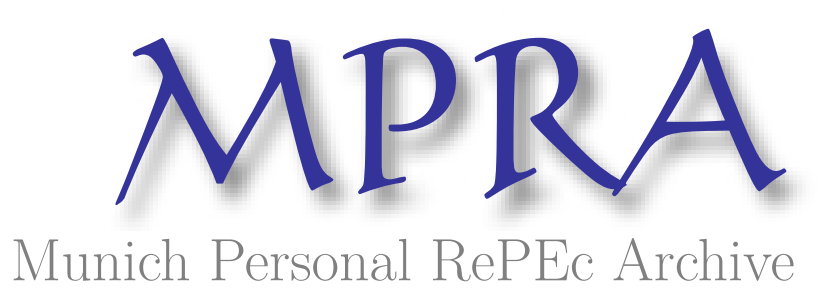

\title{
Common Denominators in White Collar Crime: I'm Special, You're Special, Let's Fleece them in Style
}

Herrman, C. S.

The Center for Research in Philosophy and Social Anthropology

24 December 2008

Online at https://mpra.ub.uni-muenchen.de/25152/

MPRA Paper No. 25152, posted 21 Sep 2010 20:14 UTC 


\title{
Common Denominators in White Collar Crime: I'm Special, You're Special, Let's Fleece them in Style
}

\author{
By \\ C. S. Herrman
}

\begin{abstract}
Culture, cults and character are shown to be the "Three C's" of graft and corruption. The notion of "conversation" is briefly allowed to link the perpetrator to his alter ego, victim or partner-in-crime, wherein are forged the origins of means, motive and opportunity —as also the ballast of the paper. The argument is made that a trained eye should expect the close interplay of culture and pathology, especially in matters of white collar crime, which is used throughout as the focus. By way of summary, these crimes are perpetrated by those with bipolar traits operating in a context of cultural permissiveness, and with selected tools (attitudes, e.g.) of cultural provenance.
\end{abstract}

More than any other single cause, a fairly simple and straightforward conversation is responsible for fraud of every description, up to and including Ponzi schemes. Whether with himself, his victim, or a partner-in crime, this conversation demonstrates how culture and disease are inter-married. In this conversation, means, motive, and opportunity are conjured, identified and settled upon. While often metaphorical in the conversation, these legal criteria will at some point manifest as actual evidence.

Conversations are exercises in fielding opportunities for exposure ${ }^{1}$ they wend back and forth between avoidance (distancing, displacement, projection) and connection (flirting, inversion, identification). Schizophrenics talk aloud to themselves in public as an exercise in using protected exposure to sublimate unmet needs. It serves much the same function in the waking state as do dreams in the sleep state. Both conversations are between one aspect of self and another. Supposing I have unmet needs for exposure, the content of the conversation with oneself might possibly suggest joining up to engage the composite self in a displacement activity. If people deserve what they get, perhaps the deployment of their underbelly as a self-justified weapon would encourage an attack at once against an enemy as well as providing a displaced advantage to the self (what they don't or shouldn't need might as well deliver a Porsche in retribution). ${ }^{2}$ The internal discussion surrounding the exposure state(s) frequently gives rise to motivations.

\footnotetext{
${ }^{1}$ Exposure as in, 'naked to mine enemies', it applies equally to exhibitionism as well as to shame, guilt, and even to dream content. Certain negative exposures are defined by the brain as "stress", indicated thereby from steroids in the urine. Some stressors, via intermediary chemical messengers, influence the epigenome, whence also the future disposition to respond in certain ways to the same stressor or its trigger. Even positive exposure, as in joy or thrill, can be interpreted as stress. The point is not to stress the "stress" in the metaphysical construction of behavior, but rather attend to the way in which the brain responds to exposures. It will be found that physiological stress has correlations with exposure, but that exposure is the source, and its modulation determines traits as well as degrees and kinds of stress reactions.

${ }^{2}$ Swindlers are wont to consider themselves "businesspeople"; businesspeople are honor-based. So here's a joke to get us started on a pleasant note: What's the difference between the honor-based and dignity-based approach to customers and clients? Answer: the honor-based swindler is fully truthful and candid in saying,
} 
Conversations with the victim variously reflect and express desires to be satisfied, fears to be averted or deleted, or paralytic states to be surmounted or otherwise supplanted. From sadism and contempt, to transference reactions, to enchantment, infatuation and masochism, the polarities (from projective distancing to identificative association) offer plentiful opportunities to survey the territory for the means to accomplish one's response to exposure, whether good or bad-more usually bad, when crime is the end result.

Conversations with a potential partner-in-crime are not what they seem, the attempt to secure a means to an end. That is rather an added bonus to the real objective, which is to ensure opportunity. Opening the right doors is really the groundwork for all purposeful projects. Where that requires a partner, a conversation will meet the requirements of the intentions. It will gain, secure and/or affirm a bond; it will build upon presupposed mutual deservedness, and it will provide, for example, opportunity for a Ponzi scheme.

\section{I}

\section{Traditional and Transactional Adults}

In 1967, a psychoanalyst by the name of Thomas A. Harris, M.D. delivered a best-seller titled, I'm Ok-You're Ok (Harper \& Row), a re-work of Eric Berne's Games People Play (Grove Press, 1964). As with Freud, this schema enlisted three psychic actors; unlike Freud, these were fashioned in good Weberian form from "types" present in actual reality: the child, the parent and the adult. Even as mere labels, there is clearly emblematic resemblance with much that we naturally associate with their referents.

This approach holds forth that the infant learns to apprehend that "I'm not Ok", whereas the baby of two years comes upon a proposition: either I'm Ok, You're not Ok", or "I'm not Ok, You're Ok". These last two possibilities run roughhouse over the personality so long as the 'adult' doesn't step in, whereat reason and realty-testing are brought to bear upon parental authoritarianism and childish immaturity. The fourth and apparently ideal condition is the adult, whose interpretation rounds out the logical possibilities: "I'm Ok, You're Ok".

Well, not so fast. Dr. Harris is grievously mistaken to presume that his fourth state cannot naturally (to say nothing of pathologically) coexist with earlier states, and indeed be controlled by them, even ruled by them. The lessons from "traditional" cultures remind us that tradition, a product of the parent-child interplay, is expected to rule the adult, however defined. From a study of all societies — of all kinds and throughout all the agesthe trend line indicates that the ideal social state occurs only upon realizing the principles of dignity and its relevance to offices and their stewardship. If actually realizing such principles is a little too heady, it cannot be too much to ask that society provide for traditional values while joining and melding with modernity. If there does exist the ideal "adult", it is one who stewards the appropriate offices, public, professional and personal, with the implicit commandment that society be a benefactor of the activity.

"Hey, if you can't take people's money and then screw 'em, then you've got no business being in the business." The dignity-based fellow says the same as a joke, as did Willie Brown, former Mayor of San Francisco, when asked how he could authorize a lawsuit by the city against tobacco companies that had donated to his campaign. Quote from Newsweek "Perspectives", July 29, 1996. 
Modernity, ideally stated, is the state in which the 'meta'-adult is capable of transcending tradition as necessary to handle change, but never to dispense entirely with it's values and certainly never to dismiss it out-of-hand. The meta-adult of modernity is nothing if not Freud's normative superego, the source of, and operating modality for, conscience. If the parent is the source of grist for conscience, the adult must continually re-educate the superego so that tradition does not stultify necessary growth and development. It is the superego that attends to these adjustments and puts them into functional reality in the stewardship of offices - the fundamental media by which we act out moral precepts. This is the true adult, not the simple adult of I'm Ok, You're Ok, where skepticism and rationalism can so often exist solely for their own sake.

Out of this caldron emerge three kinds of adult: 1) the Traditional adult of law and social expectations $;^{3}$ 2) the adult of Transactional Analysis, and 3) adults subscribing to norms of dignity in addition to the usual dictates of informed conscience. Because any society reacts to established mores through the lens of the ideal, the "normative" adult comes out of the wash pretty close to that of the third kind of adult just mentioned. From that fanciful attempt at subjective gratification incalculable woes arise. Conversations that take full advantage of this tendency will as often as not result in criminal activity.

\section{II}

\section{Society, Stress and Character}

Nothing in America prevents two bipolar capitalists from establishing a groundwork of "I'm Ok, you're Ok", and nothing but bugs and wires will detect the agreement to aggrandize others while presuming to fully deserve the ill got gains. Actually, any time two people have become overly proud of their own wherewithal, whether connected by prior business dealings or not, whether related by mafia, family or social connections or not, they are overly apt to respect too much one another's status, and for that simple reason alone are far more likely to enter into clandestine agreements on the basis that each deserves a little more of someone else's pie. "Connections" only render the task much easier, for the bar of respect has been that much lowered. It is comparatively easy for an immigrant to seek guidance and loans from his own tribe in a new country such as America, where, for example, in New York City there is a veritable web of such social philanthropy and networking.

Most traditional societies are keen observers, because keeping in touch with reality has survival value. I call them "hyper-realistic". In fact, throughout history, honor-based societies have been the chief worrywarts over a singularly troubling conundrum. I've rarely met native or traditional honor-based folks who don't practically worship their

\footnotetext{
${ }^{3} \mathrm{He}$ is the "chronological" adult in most societies, who, at a given age, becomes capable of being an adult, originally defined as being able to know and obey Tradition-specifically, its fundamental offices and their stewardship. It is why we have the saying, "Ignorance of the law is no excuse." It's a very honor-based notion, but for them even today an ideal rarely even spoken of, to say nothing of attended to. Would that the normative notion typified dignity-based offices.
} 
"freedom". "What they mean, in our lingo, is independence, and even then, only of a specific flavor, namely, the right to be their own person; to be manly, not to be dependent on others, least of all as an orphan or bastard. These are the self-same who welcome tyrants and autocrats on the basis that they restore and maintain social order and uphold values. The logic is actually sound so long as you remove from the equation any loss of the 'freedom' as we define it.

In short, the conundrum is this: how to retain the most "freedom" without risking the social order. Honor-based peoples have done their homework, have observed reality, and let it be recalled they've been around a whole lot longer than we dignity-based newcomers. Their conclusion was and remains a conservative one. They placed their bets on social shame keeping strong leaders in line (Confucianism is the example par excellence), and made sure of allegiance from the populace through customs imposing the requirement that ostentation, whether of ambition or of wealth, be coupled to a corresponding demonstration of value to the community.

From stewardship to the potlatch, clever methods have allowed ambitious men to have their freedom and still retain the veneration of tradition into the bargain, one reason why Muslim fundamentalists are, not unlike Luther, "free" in their chosen 'bondage'. 5 It also happens that they may well have done so at the risk of selecting for bipolar traits. What follows is some evidence of this possibility.

The Lakalai of New Britain chose an extraordinary way to achieve social stability in light of menfolk's weakness for certain temptations. They took to classifying members of their own society in accordance with observed patterns of behavior. In particular, and of special relevance to this discussion, they identified traits of a group answering to the call of ambition, lust, thirst for power, and the implicit self-servicing manipulation of others that makes a man dangerous to social stability. We are not to escape noticing that the same behaviors characterize many a successful capitalist.

Anthropologist C. A. Valentine ${ }^{6}$ patiently obtained the full extent of their psychoanalysis and translated the five categories that they themselves employed: 1) men of anger, who are quick to take offence, who readily quarrel and frequently resort to physical violence; 2) men of play, who clown and joke and laugh, and are fond of dramatizations and games; 3) men of movement, with a restless inability or unwillingness to remain for long in any single location; ; 4) men of diffuse attention, who repeatedly and impulsively shift from one preoccupation to another and appear to be incapable of settling down; and 5) men of sexuality, regarded as 'highly sexed', and generally, but especially sexually, uninhibited.

\footnotetext{
${ }^{4}$ Many peoples have named themselves after their word designating 'freedom'. The Franks are an early example amongst countless others.

${ }^{5}$ Luther's war over the freedom of the will with Erasmus ultimated in the jeremiad The Bondage of the Will (trans. Henry Cole, Baker Book House, 1976).

6 "Men of Anger and Men of Shame: Lakalai Ethnopsychology and Its Implications for Sociopsychological Theory," Ethnology, 2 (4), 1963, pp.441-477.
} 
These are together the pathognomonic mark of bipolar personality, meaning that they all but define what we expect from the bipolar "type". Only 30 years ago this would have far surpassed the diagnostic manual of the psychiatric association (DSM-II). The Lakalai took these not as a disorder or disease-honor-based groups will not acknowledge the existence of 'mental illness' (just ask, say, a Russian or an Iranian or a Chinaman)_but rather as a "personality". As such these traits falls short of the kind of maladjustment requiring therapy or counseling, but define instead sufficient untoward conduct as to offer predictive assessments as to expected tendencies under specified conditions, making the Lakalai veritable experts without having gone through medical school and a psychiatric residency.

Unlike us know-it-all moderns in Western society, the Lakalai do not permit bipolar types to enter positions or situations in which their tendencies will wreak havoc. They are placed where their talents best serve their own development as individuals, as well as the best interests of society. While this people is hardly a 'poster-group' for democracy, I trust the essential point has been made.

Honor-based countries are those where a person's worth is built up from respect and trust translated as such from public esteem. One's sense of worth and being thus revolves around efforts to perform tasks that directly or indirectly favor the community. In return, the community favors its own; when in trouble the community protects them, or when alone in a strange place, again the community supports them. This does not much happen in the dignity-based societies, one reason why immigrants must rely so heavily on their own kith and kin. To the Western dignity-based network, each individual is expected to care and fend for himself regardless the circumstances. It isn't "pure" dignity-based behavior by any stretch, but it does characterize every such society presently in existence.

Many honor-based societies, sufficient by percentage that we are entitled to consider the phenomenon a reasonable generalization, are organized about status. Everything is about status; where you live, what you wear, the car you drive, the school your kids attend, where you shop, who does your hair, and, most importantly, who you marry and what line of work you (and hubby) aspire to. Convention is like a needling parent, calling on you to lead the pack and positively exude status. The great legal theorist and historian Henry Sumner Main very correctly assessed man's progress as the gradual transition from "status to contract". 7 Translation: from honor-based to dignity-based society.

The contract is dignity-based because it is the agreement between individuals, and not between the individual and his family, friends or community. Of course you are able to contract with groups, but law consequently views each group-as an individual. Contracts were invented, or at least first advantaged of, by Roman society, the first dignity-based civilization. ${ }^{8}$ It was not until the rise of the West that England and America became the second and third such states.

\footnotetext{
${ }^{7}$ Ancient Law (Peter Smith, 1970), pp. 165-166. Of course he had no hint of a broad cultural typology save what travelers deduced. The honor-based and dignity-based coinages date to the early 1970's.

${ }^{8}$ That my own rendition of the typology is distinctly different from the newest investigators is here quite apparent. Compare, e.g., a devotee of the new synthesis who flatly declares Rome to be an "exemplar" of
} 
Honor-based countries typically raise their kids for success, and the Jewish, to take an example near to home, are exceedingly successful at precisely this. They have a long and storied history of making others jealous by their success at ensconcing status and success with their children from a an early age. Don't get me wrong, not all Jews are the samerecall we are treating here of generalizations, a term presupposing exceptions. The point remains well taken, if sensitive to some ears: honor-based groups generate a competitive spirit even as social rules deploy broad tactics to hide it or keep it's natural effects at bay.

The larger point is the necessary one to this discussion-between status and competitiveness, honor-based societies have introduced a great number of stressors into the mix of things. And the consequent behaviors signal the selective presence of traits that under other conditions belie something far more ominous.

While they may be serviceable for social stability, such traits only add to the environmental stressors which in so many areas are sadly bountiful. ${ }^{9}$ If it be true, as I believe it is, that environmental stressors trigger the genome to express bipolar traits, some honor-based customs risk an explosive combination. Persecutions are supreme candidates for triggering bipolar outbreaks no less than sudden and severe climatic conditions. The resulting displacements and emigrations only compound the problem.

When honor-based families or people come to America, they have generally suffered a profound stress. It sounds cheap and cheesy to say that because stress is related to bipolar traits that immigrants are apt to be prone to bipolar tendencies, but this thesis carries the baggage of too much anecdotal evidence to lay aside without remark. For some, of course, the competitive spirit and aggressive drive to succeed are given full opportunity, and these folks do not waste it. This is why immigrants have so high a success rate as to make natives almost jealous. But for so many others, the strain and stress for status, coupled with the stressors responsible for arrival here, to say nothing of making do in a very different world with no friends, no job and little money, constitutes a strain upon what coping mechanisms are available to a brain. Schizoid, bipolar and paralytic (panic and anxiety disorders) responses are reliant on traits widely dispersed and available upon the call to duty. The call is regrettably too common.

It is amazing, until you reflect on the understandings just recounted, how much graft and corruption has been the product of clever immigrants. The Ponzi scheme was hatched by an Italian immigrant-Italy, home of the Mafia. How many such organizations and gangs are foreign-born? As for the home-grown, consider the percentage of black men presently incarcerated, and the likely incidence of bipolar disorder among them. Work backwards into their communities and neighborhoods and inquire after the stressors. I am not drawing conclusions here (society turned them into criminals, ergo they are blameless victims of capitalism, etc, etc.) but instead relying on observations too numerous and

the old guard honor-based clique. See Kamir, O., Honor and Dignity in the Film Unforgiven: Implications for Sociolegal Theory. Law \& Society Review, 40. 193-232.

${ }^{9}$ Those interested in stress and climate argument of trait origination will perhaps be interested in my

"Bathing in Bipolar Semiology: The Anecdotal Evidence and the Need for Research", (December 4, 2008). Available at SSRN: http://ssrn.com/abstract=1311247. 
significant to be discounted merely because anecdotal. Persecution takes many forms, discrimination being one such. We avoid careful study of these to our detriment.

The good thing is that people generally assimilate to their new home, whence this disposition to swindling, braggadocio and dandyism melts away. Good dignity-based types simply do not swindle; it just isn't part of the dignity-based code to dis-honor dignity (while this is doctrine, not reality, it remains the case that there is significantly more of it in the H-B moiety). For the same reason it is uncommon for dignity-based societies to war with one another. ${ }^{10}$

III

\section{Cultures as a Provenance of Criminal Traits (The Honor-Based reality of Business)}

The application of the words 'honor' and 'dignity' to denote cultural typologies and then to contextualize behaviors of which we have all long been aware began some thirty-five years ago. ${ }^{11}$ Here the concern is with their utility in framing the role of business as an honor-based activity amid the otherwise dignity-based legal formulae as presented in our tripartite Constitution.

Bernard Madoff exemplifies aspects of honor-based behavior in its business guise. These are to be compared and contrasted with the normative context, where we recognize business with its own traditions and its very own code of honor: 1) accurately represent your products; 2) act as good as your word, and 3) be reliable and consistent within and between businesses. $^{12}$

Bernard Madoff took full advantage of his own people. He presented himself as a person of status and trustworthiness, a Judas among his own people for knowing they would place their full and complete trust first and foremost in one of their own. However much we can feel for his Jewish victims, rich and middling alike, and especially the Jewish charities — especially them(!) — we have to face a broader issue, namely, the common cues and clues shared betwixt Madoff and his wider ilk that we must learn better to identify. All things considered, he is not abnormal as the epitome of a "type", the white collar criminal.

\footnotetext{
${ }^{10}$ We are more accustomed to hear this said in the context of "democratic values"- but take a second look and ask what characterizes these "democratic" societies. They are all, to the last one, dignity-based or working hard at getting there. It is this, and not the fact of a given modality of governance, that truly addresses the elementary facts of social life and behavior.

${ }^{11}$ The first instance I am aware of is from Pierre Bourdieu in 1966: "The Sentiment of Honor in Kabyle Society," in J. G. Peristiany, ed., Honor and Shame: The Values of Mediterranean Society. Chicago: Univ. of Chicago Press. Peter Berger (see esp. his Homeless Mind, chapt. Excursus) flirted with the two concepts from time to time but never very systematically. Works done separately on 'honor' in societies and on 'dignity' in legal systems are the rule.

${ }^{12}$ An early (1468) view of normative business practice is that of Nider's De Contractibus Mercatorum. The following seems faintly humorous in light of current circumstances: "Business dealers who neither transport nor conserve, nor by their industry improve things... but merely buy in order to sell...should be exiled, because they prevent a direct exchange of goods and services." Charles Reeves, trans; Ronald B. Schuman, ed. (Norman: University of Oklahoma Press, 1966).
} 
Perhaps it is still just too counter-intuitive, too far a stretch, but I must insist that we work the matter through. The argument of this paper is that we must locate the requisite cues and clues in one specific composite: the bipolar personality + a permissive environment in which the sky is the limit. If it is actually the case that many "bipolar" traits are constituents of normal behavior, we can legitimately locate the sources of criminality within cultures, cults and character-the "Three C's of Corruption". Job one is ferreting out the configurations and patterns sponsored by these "three C's". 13

This section introduces honor-based configurations as the source within culture for a "climate" conducive to the composite of bipolarity and lucre. Cults and character, though they cannot be isolated from culture as islands, can, for my purposes, be discussed separately. What cannot readily be treated separately from any of the "three C's" is the potential within each for the selection or triggering of bipolar traits of relevance to criminality.

Anecdotal evidence suffices to introduce the general drift. How often have travelers complained that everyone in some given place was a liar? How often have they told of thin-skinned types, or of totally outrageous customs like honor-killings? How often have they got bug-eyed relating tales in which craft and cunning were valued attributesRobin Hood comes to mind. How often have they warned of Hungarian liars or being swindled at restaurants in any one of several East European countries recently released from Soviet control? I am not going to belabor the obvious except to affirm that the cultural common denominator is the honor-based moiety, for which judgment I assume responsibility.

The business community is not only not immune to such behavior, it is, as a culture, all too prone. You will find all degrees of severity, at any given level within the business community, of stunts to parallel the recitation just offered. Only in Mafioso-controlled business is there a consistent threat of violence, but the Ponzi schemes and cavalier reliance on derivatives have not a little in common with the attitudes of juvenile vandalism and the disposition to craft, cunning and guile so often taken for worthy methodologies in any number of cultures. There is little that any honor-based group hasn't created that some businessperson hasn't imitated or independently contrived. ${ }^{14}$

\footnotetext{
${ }^{13} \mathrm{I}$ am not saying that these are to be thought of as characterizing criminality. I am saying that these three carry, inherent to their existence and function, the potential configurations or patterns serving the would-be criminal in offering to him a portion or the entirety of means, motive and opportunity.

${ }^{14}$ By now you must think I have it in for these honor-based peoples. I confess to being a thoroughgoing dignitarian. Somewhere Erasmus remarked of the charming German inns - charming for a couple days, that is. I take the same view. In the interest of fairness, it should be said that the dignity-based cultures leave much to be desired and fall woefully short of their stated principles. If honor-based peoples are over-prone to adult childishness, insecurity and sensitivity, it must be confessed that they have us hands down in the hospitality category, and they know how to have a good time, to dance the night away. They may often be mechanically polite, but any politeness is better than some of our boorish ways. While we are refreshingly direct, we also have issues with political correctness and styles of communication that seriously trim truth and honesty, features less frequently observed in honor-based societies. In sum, our respective cultural typologies have much to learn from one another.
} 
By "cultures" I mean configurations of or within a population whereby select dispositions are markedly favored, meaning that the public at large seems to have predilections toward, or at least fails to manifest clearly articulated objections against, the behaviors under consideration, such as, in our case, opportunizing and aggrandizing. The Mafioso have for centuries nurtured a culture of corruption (what they might denote "adventurism"). Once the killing begins it is usually others of themselves who fall. Our own culture of the city "Boss" is not greatly different. Gypsies possess a lower level version of the same, but are unafraid to peddle their trade outside of the fold. And then there are the arrivals who consider us the "land of suckers". Russians, East Europeans and Nigerians seem to share those honors as of recent times.

Business has suited these honor-based types admirably. The reason is that business is itself categorically honor-based wherever found. Its essence is commerce, commodification and competition. To this mixture societies (honor-based especially) add the high esteem accorded to success, with wide variations on the craft, cunning and guile indices. $^{15}$

To understand cultural permissiveness it is also helpful to observe noneconomic examples. A Muslim professional (a reporter) throws his shoes at an American president. The culture's official doctrine is viciously strict about such matters. But the culture itself, that without which laws are valueless, has different outlooks on occasion than its laws. The "street" celebrated the reporter, and nearly all who were interviewed sympathized with his sentiment. How often has an American jury voted "nullification" and achieved much the same result?

I attended a scholarly conference once in which adolescent behavior in a South American country was singled out for discussion. It had to do with attitudes toward gays, but it rather reminded me of the pranksterism existing in so many honor-based societies where the social order, while pretending to be disturbed at the consequences, acknowledges the matter as a "boys-will-be-boys" way of settling scores or just doing the "growing up" thing. It seemed scandalous to many members of the audience. Still, seemingly modern nations like Italy are farcically prone to this nonsense. Elevate it to the level of actual hooliganism and you have the gang mentality. Elevate that to the level of ideological hatred and you have guerilla-style terrorism. ${ }^{16}$ Adding insult to injury is the foul association of the above with puerile conceptions of manhood, frequently with chauvinism and bigotry in tow.

Examples abound in American culture, of course. The "Roaring" Twenties was called 'roaring' for a reason. A culture of laissez-faire economics as the world had seldom seen

\footnotetext{
${ }^{15}$ Nothing better illustrates the ideals of honor-based culture and its natural affiliation with business than the description of Bernard Madoff by an acquaintance: "Success, philanthropy, esteem-and, if you were lucky enough to be with him as an investor, money." New York Times, 20 Dec, '08, A14.

${ }^{16}$ It is interesting to hear an expert speak of the authority of a Mafioso (capo) "The closest comparison would be with the leader of a military or paramilitary guerrilla band.” F.A.J. Ianni and E. Reuss-Ianni, $A$ Family Business (Russell Sage Foundation, 1972), p. 111. Gangs are not far different. At issue is fundamentally how authority is handled in honor-based groups. The same which is useful to society is transferred to business dealings with hardly a hitch.
} 
took hold, collapsed, and was later redintegrated in recent decades. Social historians record that housewives once considered it a duty to let in every traveling salesperson to try out the latest in American ingenuity. The culture was permissive, and thus sympathetic in a perverted sense to those who played, well, a little fast and furious at the money game. Business was for boys with big dreams and toys to match. Culture provides the atmosphere that seems to say, "go for it!" Recall that the original Ponzi, the Italian immigrant, worked in the 1920's. The twenties produced the thirties. Recent decades have led us to the current reprise. I prefer this definition of the "business cycle" to that of the economists.

Look at the culture through the second term of the Clinton administration, leading to the NASDAQ bust. Look at the current culture until just very recently. George Bush generated and enforced a culture throughout government that carried two indelible messages: Follow our definition of propriety, and, Say 'yes' to business. Lots of Bush's minions had quarrels with the first (two cabinet officers left under a cloud of doubt), but few if any had reason or motive to question the second. This has been an age in which Republicans stuck together through thick and thin, and to violate a Republican precept of any consequence was to receive a negative reward commensurate with the offence taken.

\section{IV}

\section{Cults, their Bipolar Credentials, and the Opportunity thus Inspired}

There are actually two sorts of cult. In one case a group determines to carry cultural values to a higher level, to exemplify the culture as an epitome. So soon as this group has its own rules of engagement and a common bond or spirit, we have ourselves a "cult of honor". Honor-based societies are so-named because honor is the ultimate ideal obtained from earning sufficient esteem. Those who choose to exemplify what is the very best tend to stress excellence-what Greek aristocratic types called arête. This trait accounts for the fact that it is so often the aristocratic set, or a portion thereof, that sponsors genius and innovation in a society (think of the Greek age of geniuses). Possibly every military outfit that ever existed was formed and lives under codes of a cult of honor.

The other kind of cult is either a degenerated cult of honor or a group exemplifying the other of two ways in which cults form de novo. A group that separates from a parent, and yet still presumes to better exemplify the normative cultural heritage than that parent, forms a "cult of dignity". Many religious cults are of this sort. ${ }^{17}$

\footnotetext{
${ }^{17}$ As evidence that we have lost the ability to steward offices (we give them plenty of lip service, however, as if to paper over the lacunas) let's consider the effects when a set of principles prepared as scripture (and so as dogmatic) are considered not as intended or as written but as the followers so interpret. History offers the chief grounds for splinters often termed 'denominations'. What we have failed to credit is an inconvenient truth, namely, that certain forms of logic can apply so that when scripture itself is inherently flawed, merely offering denominations does not properly erase the error. Mormons and those who are willing to accept their "But we are the 'denomination' of nice people" argument should think carefully whether it were not best to convene a convention not only to establish uniform doctrine once and for all, but to strike from scripture or highlight in shameful acknowledgement what scriptures are held in disrepute. Where suspect scripture remains unsullied, the stewardship of any religious or academic office remains unstewarded for having trimmed truth, and, in this case, having done so at untold expense in grief and misery.
} 
To start with perhaps the most glaring example that for so long escaped being widely recognized for what it has become, a veritable cult of dignity, I give you the Republican Party. To avoid claims of over-generalization, I will for sake of argument restrict the target of my remarks to the "true believers". In high cult fashion they alone have true dignity, and though they speak of dignity for all, they presume to deserve most of the rewards owed to dignity. This, the quintessence of any cult of dignity, has rarely been so well exemplified even by aristocracies which, to my recollection and knowledge, almost invariably at some point become cults of dignity.

Business leaders tend to enjoy unofficial (thus unrecognized) membership in the club of well-to-do types, which is a euphemism for another inconvenient truth, namely, that their jet-set mores are frankly aristocratic in leanings and values. Enron corporation had a fleet of private jets. A fleet. How does one wrap one's head around those few words? When a televangelist suffers disgrace the community of TV preachers have been known to gather for damage control. In at least one instance they were observed, one and all, arriving in their very own private jets. When private escapades traduce the mores of which their religion presupposes universal adherence - they have thereby allowed themselves to live above the moral law they themselves preach-perhaps the most disgraceful way a minister can besmirch the office he is charged with stewarding. It is a sterling example of the essence of the cult of dignity.

"I'm special, you're special" is an off-brand of "I'm Ok, you're Ok". Just what makes people "special"? Whatever the answer, it will be central to any consideration of opportunity. When you can look someone in the eye and conclude, while presuming the other doing likewise, that both are "special", there exists a magical bond. ${ }^{18}$ It is what cements into brotherhood what otherwise necessarily requires blood relation to kith or kin. Soldiers have one another's back, as an archetypal example. It also serves to uphold and exemplify at all cost the "style" by which so many groups, especially cults and the occasional profession, are known to the outer world.

Members of the cult of dignity find certain things remarkably easy to do. One of them is to discover kinship in another of the same cult, especially of the same sub-cult. In psycho-lingo it's called "peer clustering". Wherever it is true to say that "birds fly together", peer clustering is close at hand. The disposition bringing 'peers' together is precisely what lowers the threshold for each to assume a status where each is 'special'.

Herein lies opportunity. Chuck Colson and Gordon Libby were good dignity cultists serving the Nixon authoritarianism. Both were probably more than a little infected with bipolar traits as well, and that is a powerfully bad combination. It is why the Lakalai don't readily permit these two circumstances to coexist (we have a lot to learn from the primitives). One of the most important traits of bipolar personalities just happens to be peer clustering.

\footnotetext{
${ }^{18}$ Where a friendship presupposes and relies upon "I'm Ok, you're Ok", the common swindler sees in his partner something more, specifically, a common motivation, of a kind unique to the opportunity opened up by the partnership.
} 
Another trait, this one decidedly unpleasant, is a disposition to see others as inferior. Honor-based groups do this en mass without any psychiatric implications. The Greek word 'barbaric' means, those who are not 'us'. A related trait is misanthropy (and variants such as misogyny, dislike of women). Both traits have characterized aristocratic mentality, are more than sufficiently evidenced in boardrooms, and are together another hallmark of bipolar states. They also accentuate peer clustering within the cult and so further prefigure opportunity. Believing themselves to be better than others, because more deserving and more entitled, they also have in common the cult of dignity.

Hedge funds. Options. Derivatives. Ponzis. Defend the core idea with fancy mathematics; give it the look and feel of a solid return, and above all, remember the cardinal rule of the deal: "Perpetrators of crime rely on imputed credibility," affirmed former Ponzi-peddler Barry Minkow. "Once you've got that then people look at subjective criteria, not objective criteria to do business." He might have added that this initial "imputed" credibility need be nothing other than the shared bond by which they are equally "special". Examples include presenting oneself as a valued member of the Jewish community or as a high-ranking Republican operative. Presenting good data in support of the scheme or 'strategy' is only presenting what the introductions have presupposed. These data are accepted not because they are valid, since obviously they oftentimes are not, but because two people are mutually "special".

The cult of dignity spawns opportunity as nothing else possibly can. Look to any den of thieves for this cult. The professions, having begun their careers as cults of honor, have slowly but quite perceptibly slipped in traits of the dignity cultist. Protecting the other guy's back is now less a military equivalent than an opportunity to excuse and justify unprofessional conduct. Our society is getting to the point where one need only look to any legislature for much of the same, a shocking failure of stewardship in the most important offices vouchsafing the principles of a democracy. ${ }^{19}$

You look at a glaring case of insensitive stupidity like that of Illinois Governor Rod Blagojevich and you ask yourself, where did this behavior come from? Yes, clearly the man seems to have a bipolar personality based on the testimony of those who have known him, but here again we can't seem to get our heads around someone who simply must have known how dumb he was acting, and yet did it as if knowing and not caring, all at the same time. Is this a matter of culture, disorder, or both?

It is both. To the extent it is of pathology, it is called impaired insight, that which architect F.L. Wright haplessly possessed when honestly answering 'himself' when asked by opposing counsel who was the greatest living architect. The bipolar simply bypasses any concern for the impression of auditors. From the cultural side, this view of officeholding (i.e., as a platform for securing emoluments) is totally honor-based-so totally honor-based that he simply must have come upon some instruction or examples in his upbringing, meaning, possibly, a long mob connection we had never known of. The Mob

\footnotetext{
${ }^{19}$ Joseph Stedino, in his exposé “What's In It for Me?" (HarperCollins, 1992) restricts himself to Arizona politics, but much the same is to be found widely scattered throughout the country. Political graft continues to be endemic.
} 
is just honor-based enough, just self-satisfied and smug enough, to allow a principle like this to be passed into the education of their young. This is nothing if not the cult of dignity writ large.

\section{$\mathrm{V}$}

\section{Character, Its Bipolar Credentials, and the Opportunity It Avails}

Culture is not unlike a private discourse with the inner self. Such conversations, while entertaining and doubtless informative, are no less a source of motivation toward criminality and bipolar traits than any conversation between two parts of the self. Cults, on the other hand, are especially handy for securing one's opportunity, occasionally for criminality, and they almost without exception provide the context for any conversation between self and partner-in-crime. Finally, the character, as in the carrier for traits available in the gene pool that can be availed upon to respond to stressors: it offers the means by which motivation advantages itself of opportunity. In this section I speak of specific individuals or types of such, who, what with bipolar susceptibilities, make criminality that much more inviting, whence likely.

Bernard Madoff appeared to represent all that was well and good in a Jew. He could approach anyone with money as an equal. He could enjoy the culture of success so frequently fostered in his culture as an assurance that he and his client approached one another other as special (add to that the old-time notion of being the "chosen" of God and what-not). He could enjoy the general American culture enjoined by the Clinton and Bush administrations. He could show a track record and remain just above suspicion to nearly all. Furthermore, given that so large a percentage of his reliable clients were Jews, even his malfeasance could be exonerated under any number of excuses.

All, that is, except the one he stands accused of at present. He may have felt, as other Ponzi-peddlers before him, that he could bail himself with the same methods. But this is only a distant cousin of the old "buy yourself out of trouble" sing-song. Everyone knows in their heart of hearts that this doesn't cut it. Others refer to this behavior as falling for the "fantasy of continuous markets" where dealers and others will trade as if they always have a chance to get out. What the Ponzi-peddlers themselves have said is what makes the most sense here. "We all have a cure," explained Ponzi artist Barry Minkow. "The irony of white collar crime is we believe that we' re one good week in trading away and we'll get enough to pay it all back" (abcnews.go.com, 19 Dec, 08).

You say to yourself, How can the perpetrator be just as gullible for nonsense as his victims? The scammer knows better than anyone else that the further out one goes, the less the chance of reeling in a big one. Gamblers demonstrate the same irrationality, however, so clearly this isn't unique to just one species of stupidity. Which leads to a question: is it a matter of normality pressed to the edge, or is it the typical result when pressed past the edge — of sanity? It amounts to the distinction between a "personality" trait and a disorder or still worse, a disease state.

Bipolars are known for addictive behaviors, in every conceivable shape and size. Gambling of every sort, risk-taking at any time or place, drugs of every flavor, you name 
your addiction, I can find a bipolar who has got it or done it or both. Not all bipolars are addictive types, since most if not all of these traits are now known to be, in technical jargon, "heterogeneous", meaning, that they exist throughout the genome. They seem to agglomerate in semi-configurative manners, thus giving rise to the common syndromes. But any given trait may well find itself in anxiety here, or bipolar there. Another trait shows in autism and Asperger's, then occasionally in schizophrenia or even bipolar. They mix and match. Were they "homogeneous" they would agglomerate in statistically pleasant round figures and in nicely predictable ways, which would make psychiatric diagnosis much easier.

Addiction is a form of perverted instinct. Instincts exist to ensure continuity and completion of necessary behaviors. That many such behaviors appear naturally under exposure to danger should not be surprising given what we know of our evolutionary history (or from studying animals). Addictions short-circuit the danger-and all that hard work - and go for the gusto. It already sounds like a close relative of a Ponzi scheme, doesn't it? It figures that anyone can, under certain circumstances, fall prey to the affliction, but that the degree of danger to self or others involved is quantifiable for interventional purposes.

Occasionally we find a normal person hooking up to pain pills. An addictive personality should be very carefully monitored for any such medication. That's effectively the rule, and almost all bipolar traits have to be viewed in much the same way. Many, by themselves, are fine or at least innocent. Sometimes they are actually necessary to outstanding performance. At the wrong time, under the wrong circumstances, with the wrong dispositions and with the wrong trait combinations, things can get ugly. In bipolar disorder and disease they get ugly. People get hurt, emotionally (what ought to be the minimal criterion in disorder) or physically (disease).

At the level of Madoff we are talking disorder and disease. Few psychologists or psychiatrists will deny that much, even while idiotically ensuring to disclaim diagnosis at a distance (look where a liability-culture gets us-even otherwise intelligent people speak and act stupidly). The story of Hakam Yalincak will shortly prove instructive, for here we had a clear case of bipolar disorder/disease in a young man who later showed some (seeming) contrition and produced a tell-all summary by which to compare the remarks of others like Barry Minkow, whence both of these variants can be compared on the one hand to professional opinion, and on the other to conventional wisdom.

We could meet up with Hakam Yalincak in several ways but let's start with the one where he appears in U.S. District Court in New Haven, just prior to his co-conspiratorhis mother. Charged with single counts of conspiracy to commit wire fraud and three counts of wire fraud, they both plead not guilty. Both were from Turkey, both highly intelligent. Hakam was a mathematics major in college (a not uncommon study for future hedge fund operators, by the way). Apparently the Mrs. had been involved in numerous prior violations of similar schemes. We can fairly presume her to be the source of her son's talent for the same, having all but offered him a diploma. Disease also fits in well 
with their story, as intimated by Stamford Advocate writer Martin B. Cassidy (17 June, '05)—

A teary-eyed Ayferafet Yalin-cak exhaled loudly as a federal marshal re-shackled her at the end of the hearing. Waiting to be led from the courtroom and transferred to York Correctional Institute in Niantic, she beat a rolled up copy of the indictment against her legs.

Bipolars are notorious for being shameless, for being actors (so that's why so many highvisibility actors are bipolar...) able to turn crocodile tears on and off and charm the pants off whoever will listen, of attempting to make the innocent appear guilty - the guile common to the storied Hungarian liar (I know whereof I speak, having known a Hungarian who proved his cultural legacy in my presence-almost makes you wonder whether to postpone that Eastern European tour).

Manic bipolars are most definitely self-assured beyond reason. It is a hallmark of their general attitude toward challenges, business challenges in particular. There is a reason that executives come before Congress and lie like a den of thieves. They have contempt for the process and all its players, and they presume themselves correct in all significant matters, and these views are held forth as sacrosanct, as from on high. They are right, you are wrong. Small wonder we love them so.

Scam artists, white collar criminals and bipolars share something else in common. They are very frequently bright, talented and dashing. They are charming and convincing. Some are down-home yummy and that primitive part of the brain just wants to jump in bed with a young Yalincak. Barry Minkow, while running his Ponzi scheme thought to be worth $\$ 300$ million, took time out from his hectic days to appear on "Oprah" as a dashing young entrepreneur. Business people and other high rollers outside of business are human, all too human. But then, they, unlike the rest of us, are special; they are laws unto themselves.

A final commonality, and one of the most intriguing and comical: these folks are brazen. They do not merely lie, they lie with nerve and verve. They don't simply feel contempt for their victims, they symbolize their contempt on what they spend their ill-got gains. When they are challenged, and even when seemingly trapped, they are the rock of Gibraltar. There is not an insecure or uncertain piece of cartilage to be found. The reporter who grilled Madoff just before his arrest said of his demeanor that it was the performance of a lifetime. Actors, one and all. Talk to any detective; watch Law and Order; what you see in the main are bipolar types doing what they are best at: acting. Ditto for inveterate liars and over-the-top sharp hagglers.

VI

\section{A Summary View, All the Pieces in Place}

When Hakam Yalincak told his story, every judge in the land, and every politician as well, should have read the transcripts. If I had to reduce it all to a single phrase, as in the present instance I have little choice but to do, I would after careful deliberation settle on his answer to the general question, Why did it work? It worked, he said, because he could 
walk confidently into an office and presume to proceed on the common truism of highstakes business: "Greed is good."

Wherever in capitalism two competing oligarchs get together, we expect the ominous. We expect two oligarchs to achieve a two-punch tête-à-tête: it starts out with, "I'm special, You're special," and concludes with, "Together we can be deserving of even more. The sky is the limit" Once the plan is operationalized, middle-America is just that much further marginalized.

Oligarchs are usually your garden variety of self-interested aristocrat. Elitist, presuming to entitlement, supercilious and often outright contemptuous of lesser sorts, this type executive leans toward arrogance, thinks to be automatically correct, and considers those in opposition to be fools, idiots, or worse (yes, Alice, there is a "worse"). I hasten to add that these are some of the self-same characteristics of bipolar disorder. In fairness to the larger argument it should also be remarked that these traits frequent traditional societies in which 'custom' rules with an iron fist (think of Mugabe types).

The usual objective of the "three C's" is control, whether to lord over, dominate or manipulate. Oligarchies want control over pricing and they want to avoid undue competition (the federal legislature has implemented policies ensuring much the same regarding their own offices). Aristocracies want control over birthrights and escutcheons, certainly, but the feature least put on display but ultimately one of the most noted, is that of wanting to be a breed apart, meaning they tend to increase prevailing tendencies that separate rich from poor, the powerful from the powerless.

In Transactional terms, oligarchies, wherein adults seem rather to behave as bad children, can be said truly to represent our inner 'child'. Aristocrats carry the authoritarianism and protective elements of the 'parent', while any successful meritocracy arrives paralleling the adult; but too often throwing in with one of the others. A truly dignitarian society requires an aretocracy, after the Greek arête. ${ }^{20}$

Marty O'Connell was a market-maker on the Chicago Board Options Exchange from 1977 until 1984, before branching out into managed futures accounts, management consulting and seminars. Asked how he got his start in the big leagues, he candidly allowed this:

Option-trading brings out certain kinds of behavior; mostly human weakness rather than strength. The most difficult thing to find is a trader who can take a big loss and not have it upset him to the point that he changes his behavior. The second most difficult thing to find is a trader whose perspective is not affected by an unusually large gain. ${ }^{21}$

\footnotetext{
${ }^{20}$ It's not the actual Greek product we are after but the ideals they understood as the foundation for their efforts, such as they were (not to disclaim their Olympics and statuary, of course).

${ }^{21}$ Interviewed by Joe Kolman, online at:

http://www.derivativesstrategy.com/magazine/archive/1999/0999qa.asp).
} 
David Brooks of the Times (7 Oct., '08) got to talking with some market folks and brought back much the same conclusion. "The traders in charge of these trillions become bipolar as a result of their uncertainty," he notes, adding that "when these traders are in their manic phase, they flood countries and economic sectors with capital." Another manic trait he mentions, and this is a biggie: "When things are going well, they don't think they're just lucky and riding a wave. They're infused with a sense that they have it all figured out."

Between a culture that rewards an attitude capable of assenting to the "greed is good" dictum (blend in the honor-based bag of tricks), and a cult of dignity presupposing themselves the superior race, above the law, and generally misanthropic as well as chauvinistic and bigoted, we need only add the character traits of the bipolar that have been reviewed. There are of course many more, but we have seen enough of these traits to make a good generalization and run with it.

Between you, me and the lamppost, if I had to choose whether to believe an executive who denied the allegation that business is conducted under the "greed is good" banner on the grounds that the accuser was a felon and many worse things, versus believing a bipolar having his kicks with nothing to lose and everything (psychologically if not materially) to gain by telling the truth-the more shocking the better-I can tell you confidently that I would in every case believe the bipolar. It's just good psychology. A bipolar leads a harried and eclectic existence where the truth is more than satisfactory for most expository purposes. Contrary to the popular imagination, bipolars don't lie except as part of a game or scam, for there is less emotional, often also intellectual, need to liebeyond involvement in crime, of course.

* $\quad * \quad *$

To be "special" and to know there is a bond communicating the same sentiment in reverse is enhanced by cultures that invite oligarchic and aristocratic types to rule the roost un-beholden to regulators or to the stewardship of their offices. Given opportunistic circumstances, the bipolar, in common with aristocrats and the business elite, will likely be narcissistic, comfortable with an "entitlement" mindset, in short, a considered disposition to feel "special". Madoff investors speak of "that special lure-the sense that they were being allowed into an inner circle, one that was not available to just anyone" (New York Times, 20 Dec, '08, A14).

Every cult is practically by definition a culture that nourishes the belief in the member's special place as a true believer. The Christian Right treated George Bush as a true believer and they would have voted for him had he been Hitler's secret advisor. The true believer does no wrong, you understand. You do understand, don't you?

So when I require the condition that two individuals with ulterior prospects of lucre (with that comes power, influence and the rest) come together as sharing something "special", I am not whistling Dixie. I believe that truly is what it amounts to. Were there not something "special" to be identified with, something having the character of a bond, the transaction would be far more impersonal, non-familiar (recall the ethics of the good waiter: friendly but not familiar), and much more prone to fall under standard norms of propriety and ethics. 
The mind can project what it needs to identify with. Bernard Madoff played 'hard to get' so that upon finally meeting him, the requisite 'special' bond had been manufactured if not also tightened a tad. Being hard to get is a little like being late to appointments. One vicariously controls a situation. In rare moods bipolars are supremely good at it. ${ }^{22}$

For each, whether criminal-partner or criminal-victim, to be somehow special and thus apart, seems somehow to permit the extension toward other adverbs, thus allowing this special affiliation to elevate them above others, and by one simple additional extension, above their laws as well. This adequately sets the stage. Where we can all agree upon greed; where we are special and deserving, we are thusly deserving of all that we can amass. If we can do this more effectively together, how can it be brought about?

In rare instances these are highly valued cultural attributes. Being exotic helps, too. French, Italian, Arab or African examples come on the news channels from time to time. More usually, the aloofness and superciliousness are, along with a bit of arrogance, the traits of all three bipolar types depending upon circumstances. How do you tell the difference, therefore, from a custom or cult here, and a disease there? Cultures, no less than exposure and stress, can 'select' traits for emphasis simply by promoting the requisite permissiveness. The traits are all there, in the gene pool, the issue being only the circumstances under which they will express. They are only traits. As such, as traits, they have no necessary relation to pathology excepting as nature or mankind may provide.

The flip side is unexpectedly good - there is nothing wrong with having bipolar traits; many of them are the source of all that is best in us. The only-and not so good a one as I should like-rational reason for even calling them "bipolar traits" at all is only and simply because: the bare fact of the matter happens to be true. The same traits that accompany so much that is great, also accompany white collar crime, and that ties to honor-based group formations that complete the continuity for presenting the very same set of traits into the bargain.

If we are going to give the collection of traits a name, and one happens already to be available and in currency, well, our lazy habits assume control and judgment follows along. I simply cannot think of an adequate coinage, and in any case I am not so sure that the association of the word bipolar with the 'badder' sort is not without a silver lining.

While the dignity-based are not nearly as bad as the honor-based at facing up to guilt and mental discomfiture, still it comes with difficulty, and as frequency breeds habituation, so it permits a daring conversation with the darker side, but on friendlier terms. We simply must get to the point where we can allow certain inconvenient or uncomfortable truths to be aired, just as we air, as the saying goes, our 'dirty laundry'-something else an honorbased person is likely to be ill-at-ease with.

\footnotetext{
${ }^{22}$ Frank Lloyd Wright's wife was his perfect match in both health and disease, dictating who among his students would date whom. He would design furniture into the wall, never mind the prospective owner's taste. A good bipolar, like a good Mafioso or politician, can 'handle' a room, or a client; the moves are effortless because built in.
} 
